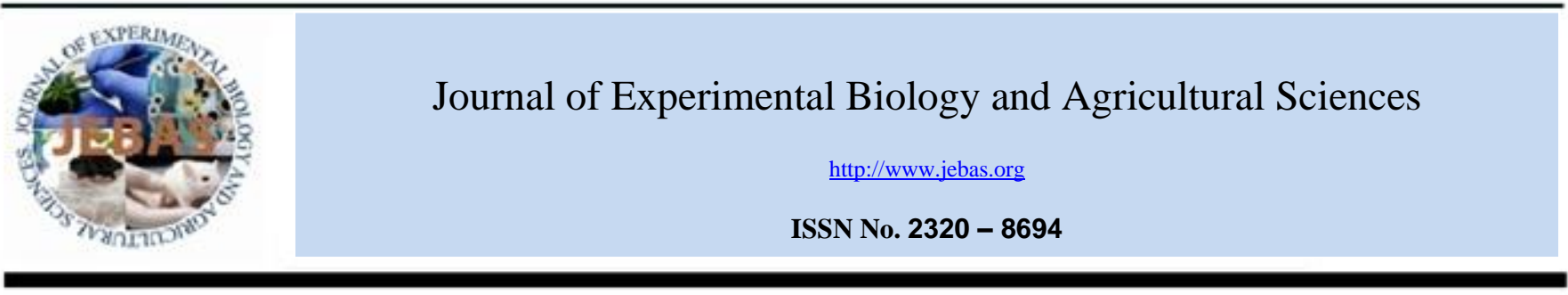

\title{
ECONOMIC ANALYSIS OF OPEN FIELD CHILLI (Capsicum annuum L.) PRODUCTION IN PUNJAB, PAKISTAN
}

\section{Muhammad Tariq Iqbal Khan ${ }^{1}$, Qamar Ali $^{2,}{ }^{*}$, Muhammad Ashfaq ${ }^{3}$ and Muhammad Waseem ${ }^{4}$}

${ }^{1}$ Lecturer, Department of Economics, Government Postgraduate College, Jaranwala, Pakistan.

${ }^{2}$ Institute of Agricultural and Resource Economics, University of Agriculture, Faisalabad, Pakistan and Instructor, Department of Economics, Virtual University of Pakistan, Faisalabad Campus, Pakistan.

${ }^{3}$ Professor and Doctor, Institute of Agricultural and Resource Economics, University of Agriculture, Faisalabad, Pakistan.

${ }^{4}$ The Zarai Taraqiati Bank Limited, Toba Tek Singh Branch, Toba Tek Singh, Pakistan.

Received - January 23, 2017; Revision- February 11, 2017; Accepted - February 28, 2017

Available Online - February 28, 2017

DOI: http://dx.doi.org/10.18006/2017.5(1).120.125

KEYWORDS
Benefit cost ratio
Cobb-Douglas
Gross income
Net income
Vegetables

\begin{abstract}
Vegetable are a basic component of food security and necessary to meet the increasing food demand of increasing population. Present study was designed to explore the cost, revenue and modeling of revenue with different inputs in open field capsicum/bell pepper production in Punjab, Pakistan. Total 70 respondents were interviewed with stratified random sampling in 2014. Total cost (Rs. 277,064.82) was higher for small farmers and it was followed by large (Rs. 258,178.11) and medium (Rs. 256,496.42) farmers. Total production $\left(21,209.27 \mathrm{~kg}\right.$ acre ${ }^{-1}$ ), average price (Rs. 25.33 per $\mathrm{kg}$ ) and revenue (Rs. 537,264.67 acre $^{-1}$ ) were higher for small farmers. According to BCR, medium farmer received Rs. 2.02 by investing rupee one in this activity followed by small (Rs. 1.94) and large (Rs. 1.70) farmers. Result showed a positive impact on revenue due to education, experience in capsicum production, extension services and labor cost. The revenue coefficient was negative for land preparation and chemical cost. Model was appropriate according to $\mathrm{R}^{2}(0.707)$ and f-value (16.006). Unstable prices, less extension services, disease attack and impure inputs were main problems. Government should eliminate these problems and improve the technical knowledge/training of farmers. Government should ensure the quality of agricultural inputs such as fertilizers, sprays and seed.
\end{abstract}

* Corresponding author

E-mail: qamarali2402@gmail.com (Qamar Ali)

Peer review under responsibility of Journal of Experimental Biology and Agricultural Sciences.

Production and Hosting by Horizon Publisher India [HPI] (http://www.horizonpublisherindia.in/).

All rights reserved.
All the article published by Journal of Experimental Biology and Agricultural Sciences is licensed under a Creative Commons Attribution-NonCommercial 4.0 International License Based on a work at www.jebas.org.

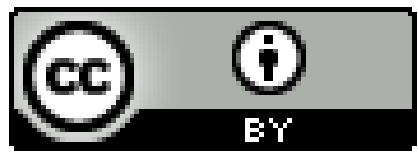




\section{Introduction}

Agriculture occupied a major $(20.9 \%)$ share in the gross domestic product of Pakistan with the involvement of $43.5 \%$ labor force (Government of Pakistan, 2016a). Total cropped area was 23.40 million ha in Pakistan (Muhammad et al., 2015) but vegetables occupied only 0.386 million ha in the production of total 3116808 tones vegetables (Government of Pakistan, 2016b). There exists $2.18 \%$ increase in per capita monthly vegetable consumption from $4.13 \mathrm{~kg}$ (2011-12) to $4.22 \mathrm{~kg}$ (2013-14) in Pakistan (Government of Pakistan, 2015a). Export of fruits, vegetables and condiments increases 9.17\% from Rs. 2366.48 billion (2012-13) to Rs. 2583.46 billion (2013-14) while import of these items increases by $0.29 \%$ from Rs. 4630.52 billion (2013-14) to Rs. 4644.15 billion (2014-15) (Government of Pakistan, 2015b \& 2016b). It showed the deficit in the trade of vegetables, fruits and condiments in Pakistan.

Capsicum (Capsicum annuum L.) is a popular vegetable crop, commonly known as bell pepper or sweet pepper or hot pepper or chilli. It was consumed as a spice, vegetable, pickle, condiment and sauce. Internationally, chillies are consumed as a spice and become an ingredient in medicines and beverages (Daundkar \& Bairagi, 2015; Velayutham \& Damodaran, 2015). Green chillies provide proteins, minerals, vitamin A and $\mathrm{C}$ while dry chillies are known as a source of vitamin A and D (Patel, 2014).

International area under chilli production was 19.89 million ha with a production of 33.52 million tonnes (Patel, 2014). Among various chilli grown countries, India (13 million tones or $38.78 \%$ ) is the largest chilli producing country and it was followed by China (3 million or $8.65 \%$ ) (Patel, 2014). In case of productivity (tons/ha), China occupied first position (6.74 tons/ha) and it was followed by Pakistan (2.31 tons/ha), Tailand (2.23 tons/ha), Mexico (1.85 tons/ha), Bangladesh (1.74 tons/ha), Nigeria (1.72 tons/ha), World (1.68 tons/ha), India (1.64 tons/ha), Vietnam (1.45 tons/ha), Myanmar (0.97 tons/ha) and Romania (0.87 tons/ha), this things shows the potential of chilli production in Pakistan(Patel, 2014).

But, the area under chilli production was decreased by $2.68 \%$ from 64,175 ha (2007-08) to 62,456 ha (2014-15) in Pakistan. Irrespective of that fact, total production of chilli showed a tremendous increases (20.32\%) from 11,101 tonne (2007-08) to 139,687 tonnes (2014-15) within 8 years (Government of Pakistan, 2013; Government of Pakistan, 2016b). It showed $23.62 \%$ increase in the yield from $1809.13 \mathrm{~kg} \mathrm{ha}^{-1}$ (2007-08) to 2,236.5 $\mathrm{kg} \mathrm{ha}^{-1}$ (2014-15) which showed its growth in Pakistan. On the other hand, area under chilli production was increase by $12.83 \%$ from 5121 ha (2007-08) to 5,778 ha (201415) in Punjab. Similarly, total chilli production was increased $15.93 \%$ from 8,087 tonnes (2007-08) to 9,377 tonnes (201415) while yield was increased $2.77 \%$ from $1,579.18 \mathrm{~kg} \mathrm{ha}^{-1}$ (2007-08) to $1,622.88 \mathrm{~kg} \mathrm{ha}^{-1}(2014-15)$. It reflects the popularity of chilli production in Punjab (Government of Pakistan, 2013; Government of Pakistan, 2016b).

Punjab province is located between $24-37^{\circ} \mathrm{N}$ and $62-75^{\circ} \mathrm{E}$ in the fertile land of five south flowing rivers (Farooqi et al., 2007). Region is blessed with a good climate, suitable for vegetable production in open field and tunnel farming (Muhammad et al., 2015). In 2012-13, top ten leading vegetable producing areas were Gujranwala (11463 ha) followed by Faisalabad (9489 ha), Sheikhupura (9076 ha), Okara (7914 ha), Sahiwal (7728 ha), Khanewal (7288 ha), Kasur (6700 ha), Lahore (5745 ha), Rahimyar Khan (5587 ha) and Toba Tek Singh (4642 ha) (Government of Pakistan, 2015c).

Due to its importance, a fine literature is available about the economic analysis of capsicum production especially in India. But literature was not satisfactory about the economic analysis of capsicum in Punjab, Pakistan. Therefore, a comprehensive study is required about the economic analysis and modeling of output and inputs in open field capsicum production.

In a study, Sanusi \& Ayinde (2013) designed the study to investigate the profitability in pepper production in Nigeria. The mean of different socio-economic characteristics were estimated such as age (43 years), pepper growing experience (12 years), family size ( 8 persons) and farm size (1.23 ha). On average, the variable and fixed cost were N 228,293.06 (US\$ $1,521.95$ ) and $N 9,765.49$ (US\$ 65.10), respectively to receive the average revenue of $\mathrm{N} 622,847.56$ (US\$ 4,152.32). The return to investment ratio was 2.62 .

Similarly, Olayiwola (2014) performed the economic analysis of chilli production in Nigeria. On per acre basis, total cost was estimated for small $(34,225.05$ Naira $)$, medium $(38,612.48$ Naira) and large (42,086.84 Naira) farmers. The gross income was higher for large farmers $(73,883.49$ Naira) and less for small $(49,104.38$ Naira) farmer. Similarly, large farmers had higher benefit cost ratio (1.91) as compared with medium (1.87) and small (1.56) farmers.

Recently, Daundkar \& Bairagi (2015) explored the economics of capsicum in India. Total cost was Rs. 125,260 with net returns (Rs. 273,388) and input-output ratio (3.11). Velayutham \& Damodaran (2015) demonstrated the economic performance of chilli production in India. Regression coefficients of Cobb-Douglas model were positive for labour man-days (0.406), manure (0.0778), fertilizer (0.368) and chemicals (0.251).

In the light of above facts, present study was aimed to estimate the total production cost, total revenue, benefit-cost ratio, gross margin, net income and determinant of revenue in open field capsicum production. 


\section{Materials and Methods}

This study was based on primary data, collected from 70 open field capsicum growers in 2014 from districts Faisalabad and Toba Tek Singh, Pakistan. For large size population, a sample of 60 respondents was appropriate for better results (Poate \& Daplyn, 1993; Mari, 2009). Stratified random sampling was adopted because it was helpful when total population was distributed into various sub-groups and a sample was taken from each sub-group on random basis (Teddlie \& Yu, 2007). Respondents were divided into three sub-groups such as small, medium and large farmers. Total operational land was less than 12.5 acres for small farmers; more than 25 acres for large farmers; and between 12.5 and 25 acres for medium farmers (Hassan et al., 2005). Small, medium and large farmers were $44.3 \%, 30.0 \%$ and $25.7 \%$, respectively for present study.

\subsection{Estimation of costs and returns}

For economic analysis, total revenue (TR) and total cost (TC) were estimated in open field capsicum production. Total variable cost was calculated by the addition of cost incurred on land preparation, seed, transplantation, fertilization, earthling up, hoeing, irrigation, pesticides, picking and marketing. Total fixed cost was the sum of land rent (six months), administration charges, interest on variable cost (Mwangi, 2012) and abyana (Noonari et al., 2015). An interest rate of $8 \%$ was also applied for empirical analysis.

Benefit-cost ratio, gross margin and net income were calculated with given formulas (Ali et al., 2016):

\subsubsection{Benefit Cost Ratio (BCR)}

BCR is obtained by dividing total revenue (TR) with total cost (TC). It explains the amount of revenue for the investment of one rupee as total cost.

$\mathrm{BCR}=\frac{\mathrm{TR}}{\mathrm{TC}}---------(1)$

\subsubsection{Gross Margin (GM)}

It is obtained by subtracting variable cost (VC) from total revenue (TR).

$\mathrm{GM}=\mathrm{TR}-\mathrm{VC}-------(2)$

\subsubsection{Net Income (NI)}

It is obtained by subtracting total cost (TC) from total revenue (TR).

$\mathrm{NI}=\mathrm{TR}-\mathrm{TC}------(3)$
2.2 One-way analysis of variance (ANOVA)

ANOVA explored the difference in the mean values for various sub-groups (Ostertagová \& Ostertag, 2013) by using following null and alternative hypothesis:

Null hypothesis $\mathrm{H}_{0}$

$$
\mu_{1}=\mu_{2}=\mu_{3}
$$$$
\text { Alternative hypothesis } \mathrm{H}_{1}: \quad \mu_{1} \neq \mu_{2} \neq \mu_{3}
$$

Equality and difference in the mean values of sub-groups was explored by null and alternative hypothesis, respectively.

\subsection{Econometric Model Specification}

Easy estimation and interpretation of results is a major advantage of Cobb-Douglas model (Heady \& Dillon, 1961), Later, Beattie \& Taylor (1985) introduced the logarithmic transformed form of Cobb-Douglas model because of easy coefficient estimation in linear form as:

$$
\begin{aligned}
\ln Y=\operatorname{lna}+\beta_{1} \ln X_{1} & +\beta_{2} \ln X_{2}+\beta_{3} \ln X_{3}+\beta_{4} \ln X_{4}+\beta_{5} \ln X_{5} \\
& +\beta_{6} \ln X_{6}+\beta_{7} \ln X_{7}+\beta_{8} \ln X_{8}+\beta_{9} \ln X_{9} \\
& +\ln U_{i}-------(4)
\end{aligned}
$$

Where;

$\begin{array}{lll}\mathrm{Y} & = & \text { Average revenue (Rs.) } \\ \mathrm{X}_{1} & = & \text { Education (Years) } \\ \mathrm{X}_{2} & = & \text { Contacts with extension agents (No) } \\ \mathrm{X}_{3} & = & \text { Open field capsicum/bell pepper } \\ & & \text { experience (Years) } \\ \mathrm{X}_{4} & = & \text { Land preparation cost (Rs.) } \\ \mathrm{X}_{5} & = & \text { Seed cost (Rs.) } \\ \mathrm{X}_{6} & = & \text { NPK (Kg) } \\ \mathrm{X}_{7} & = & \text { Chemical applications Cost (Rs.) } \\ \mathrm{X}_{8} & = & \text { Irrigation cost (Rs.) } \\ \mathrm{X}_{9} & = & \text { Labour cost (Rs.) } \\ \mathrm{ln} & = & \text { Natural logarithm } \\ \mathrm{a} & = & \text { constant } \\ \mathrm{Ui} & = & \text { Error term which shows the effect of } \\ \beta_{1 \ldots . .} & \beta_{12}, \text { are coefficients of estimates. }\end{array}$

\section{Results}

Table 1 reveals the mean and ANOVA of socio-economic variables. On an average, large farmers had more education (10.50 years), operational land (36.03 acre), contact with extension agents (4.11), open field capsicum production area (1.06 acre) and experience in open field capsicum (6.64 years). Age (41.10 years) and family size (9.52) was more for medium farmers. The difference in mean was insignificant for age, family size and open field capsicum area but it was significant for education, land holding, contacts with extension agents and experience in open field capsicum. 
Table 1 Mean and ANOVA of various socio-economic variables.

\begin{tabular}{|l|cccccc|}
\hline Particulars & \multicolumn{3}{c|}{ Farm Size Category } & \multicolumn{2}{c|}{ ANOVA } \\
& Small & Medium & Large & F-value & Sig. \\
\hline Age (years) & 39.58 & 41.10 & 39.83 & 0.091 & 0.913 \\
\hline Education (years) & 6.52 & 8.76 & 10.50 & 5.288 & 0.007 \\
\hline Family Size & 8.45 & 9.52 & 7.50 & 1.699 & 0.191 \\
\hline Total operational holding (acres) & 6.41 & 15.74 & 36.03 & 200.288 & 0.000 \\
\hline Contacts with extension agents & 3.19 & 3.81 & 4.11 & 3.529 & 0.035 \\
\hline Open field capsicum experience (years) & 4.68 & 5.79 & 6.64 & 3.096 & 0.052 \\
\hline Open field capsicum area (acres) & 0.95 & 1.01 & 1.06 & 0.587 & 0.559 \\
\hline
\end{tabular}

Table 2 depicts the average variable cost incurred in per acre production of open field capsicum. On average, expenditures of large farmer were high on seedling transplantation (Rs. 3,717.44) and hoeing (Rs. 4,151.39). On average, medium farmer spend more financial resources on land preparation (Rs. 13,759.54) and irrigation (Rs. 8,127.98). On average, small farmers spend more money on seed (Rs. 7,517.95), fertilization (Rs. 47,118.55), earthing up (Rs. 2,568.13), picking (Rs. 37,613.23), pesticide and weedicide (Rs. 21,363.88) and marketing (Rs. 93,298.88). Total variable cost was more for small farmer (Rs. 237,375.02) followed by medium (Rs. 218,738.53) and large farmer (Rs. 218,450.98). Large farmer paid more land rent (Rs. 24,347.22) while interest on variable cost (Rs. 9,495.00), administrative cost (Rs. 7121.25) and abyana (Rs. 89.68) were higher for small farmer. Total production cost was also higher for small farmer (Rs. 277,064.82).

Table 3 describes that the small farmers get more production $\left(21,209.27 \mathrm{~kg} \mathrm{acre}^{-1}\right)$ and price (Rs. $\left.25.33 \mathrm{~kg}^{-1}\right)$. The difference in the average price received by different sub group was found insignificant. Total revenue was also more for small farmers (Rs. 537,264.67 acre ${ }^{-1}$ ). Both GM (Rs. 300,118.06 acre ${ }^{-1}$ ) and NI (Rs. 262,360.17 $\mathrm{acre}^{-1}$ ) were more for medium farmer. BCR was high for medium farmers (2.02) followed by small (1.94) and large (1.70) farmer. It depicts that medium farmer received Rs. 2.02 in return by investing rupee one in open field capsicum production.

Table 4 explains the acceptability of Cobb-Douglas model for capsicum according to $\mathrm{R}^{2}(0.706)$, adjusted $\mathrm{R}^{2}(0.662)$ and $\mathrm{f}$ statistics (16.006). The regression coefficient was significant and positive for education which shows $0.066 \%$ increase in revenue for $1 \%$ increase in education. The increase in revenue was $0.172 \%$ and $0.130 \%$ due to $1 \%$ increase in experience and labour cost, respectively. The revenue was decreased by $0.213 \%$ and $0.094 \%$ as a result of $1 \%$ increase in land preparation cost and chemical (pesticide) cost respectively.

Table 2Total production cost acre ${ }^{-1}$ (Rs.) in open field capsicum

\begin{tabular}{|c|c|c|c|c|}
\hline \multirow[t]{2}{*}{ Production Practices/ Costs } & \multicolumn{3}{|c|}{ Sub-Groups } & \multirow{2}{*}{$\begin{array}{l}\text { Standard Error } \\
\text { of Mean }\end{array}$} \\
\hline & Small & Medium & Large & \\
\hline Land Preparation & 13040.66 & 13759.54 & 13457.03 & 361.96 \\
\hline Seed & 7517.95 & 7051.81 & 7387.65 & 157.14 \\
\hline Seedling Transplantation & 3486.06 & 3349.21 & 3717.44 & 173.74 \\
\hline Fertilization & 47118.55 & 37416.67 & 46436.11 & 2755.20 \\
\hline Hoeing & 3698.32 & 3376.82 & 4151.39 & 248.09 \\
\hline Earthing up & 2568.13 & 1900.42 & 1952.65 & 162.18 \\
\hline Pesticide + Weedicide & 21363.88 & 20094.99 & 18547.99 & 635.76 \\
\hline Irrigation & 7669.35 & 8127.98 & 7163.58 & 303.76 \\
\hline Picking & 37613.23 & 30703.80 & 31182.05 & 1623.08 \\
\hline Marketing & 93298.88 & 92957.30 & 84455.09 & 2223.17 \\
\hline Total Variable Cost (TVC) & 237375.02 & 218738.53 & 218450.98 & 4494.13 \\
\hline Interest on TVC @ 8\% (6 months) & 9495.00 & 8749.54 & 8738.04 & 179.77 \\
\hline Administrative cost ( $3 \%$ of TVC) & 7121.25 & 6562.16 & 6553.53 & 134.82 \\
\hline Land Rent (Six Months) & 22983.87 & 22357.14 & 24347.22 & 635.00 \\
\hline Abyana & 89.68 & 89.05 & 88.33 & 2.44 \\
\hline Total Cost & 277064.82 & 256496.42 & 258178.11 & 4903.97 \\
\hline
\end{tabular}


Table 3 Economic analysis of per acre open field capsicum production.

\begin{tabular}{|lcccc|}
\hline Indicator/Unit & \multicolumn{2}{c}{ Sub-Groups } & Large & $\begin{array}{c}\text { Standard Error } \\
\text { of Mean }\end{array}$ \\
\cline { 2 - 5 } & Small & Medium & 18953.06 & 578.03 \\
\hline Production $(\mathrm{Kg})$ & 21209.27 & 20706.31 & 23.19 & 0.61 \\
\hline Average Price $\left(\mathrm{Rs.} \mathrm{Kg}^{-1}\right)$ & 25.33 & 25.06 & 13.62 & 0.40 \\
\hline Average Cost (Rs. $\left.\mathrm{Kg}^{-1}\right)$ & 13.06 & 12.39 & $439556.34(4194.44 \$)$ & 17813.08 \\
\hline Total Revenue (Rs.) & $537264.67(5126.82 \$)$ & $518856.59(4951.16 \$)$ & 17085.37 \\
\hline Gross Margin (Rs.) & $299889.65(2861.68 \$)$ & $300118.06(2863.86 \$)$ & $221105.35(2109.88 \$)$ & 17249.93 \\
\hline Net Income (Rs.) & $260199.85(2482.94 \$)$ & $262360.17(2503.56 \$)$ & $181378.23(1730.79 \$)$ & $\mathbf{0 . 0 7}$ \\
\hline BCR & $\mathbf{1 . 9 4}$ & $\mathbf{2 . 0 2}$ & $\mathbf{1 . 7 0}$ & $\mathbf{0 2}$ \\
\hline
\end{tabular}

\section{Discussion and Conclusions}

Open field capsicum production is a profitable activity and it was in line with the results of Sanusi \& Ayinde (2013), Olayiwola (2014) and Daundkar \& Bairagi (2015). Per acre cost of chilli production was N 35,264.12 (Rs. 11,763.12) with a BCR score of 1.78 in Nigeria (Olayiwola, 2014) which was close to the findings of current study. Positive education coefficient was in line with previous studies (Ibekwe \& Adesope, 2010; Mwangi, 2012; Khan \& Ghafar, 2013; Mohammed, 2015). An educated farmer has the ability to understand new technology and learns about better production practices. The increase in revenue due to increase in experience was in line with Ibekwe \& Adesope (2010). Chemical cost placed negative impact because many farmers used chemicals to avoid disease attack without consulting an agronomist or entomologist. Positive coefficient of labour cost was in line with Khan \& Ghafar (2013), Mari (2009) and Mwangi (2012)

Price instability, high middle man margin, expensive inputs, low quality inputs, lack of extension services and disease attack were the major issue as told by the respondents. Due to these problems, farmers prefer the cultivation of staple food crops with attractive support price like wheat. Government should improve the services of extension department, to aware the farmers about optimum utilization of resources such as fertilizer, water and pesticides. Government should establish farmer field schools for the training of farmers about modern practices in agriculture. Monitoring teams should check the quality of agricultural inputs in retail market.

\section{Conflict of interest}

Authors would hereby like to declare that there is no conflict of interests that could possibly arise.

\section{References}

Ali Q, Ashfaq M, Khan MTI (2016) An economic analysis of off-season capsicum/bell pepper production in Punjab, Pakistan. ARPN Journal of Agricultural and Biological Science 11: 424-430.

Beattie BR, Taylor CR (1985) The economics of production. Wiley, New York.

Table 4 Regression results of Cobb-Douglass production function.

\begin{tabular}{|c|c|c|c|c|}
\hline Variables & Unit & Coefficient & $t$-value & $p$-value \\
\hline Constant & & $14.291 *$ & 10.109 & 0.000 \\
\hline ln-education & Year & $0.066 * * *$ & 1.904 & 0.062 \\
\hline ln-contacts with extension agents & No. & $0.270^{*}$ & 4.043 & 0.000 \\
\hline ln-capsicum growing experience & Year & $0.172 *$ & 4.504 & 0.000 \\
\hline ln-land preparation cost & Rs. & $-0.213 * *$ & -2.329 & 0.023 \\
\hline ln-seed cost & Rs. & -0.057 & -0.564 & 0.575 \\
\hline $\ln -\mathrm{NPK}$ & $\mathrm{Kg}$ & -0.024 & -0.498 & 0.621 \\
\hline ln-chemical cost & Rs. & $-0.094 * * *$ & -1.791 & 0.078 \\
\hline ln-irrigation cost & Rs. & 0.018 & 0.374 & 0.710 \\
\hline ln-labour cost & Rs. & $0.130 * * *$ & 1.738 & 0.087 \\
\hline $\mathbf{R}^{2}$ & 0.706 & & & \\
\hline Adjusted-R $^{2}$ & 0.662 & & & \\
\hline F-ratio & 16.006 & & & \\
\hline
\end{tabular}

*significant at $1 \%, * *$ significant at $5 \%, * * *$ significant at $10 \%$ 
Daundkar KS, Bairagi SK (2015) Economics of production of capsicum in Akola district. International Journal of Commerce, Business and Management 8: 81-83. DOI: 10.15740/HAS/IJCBM/8 .1 /81-83.

Farooqi A, Masuda H, Firdous N (2007) Toxic fluoride and arsenic contaminated groundwater in the Lahore and Kasur districts, Punjab, Pakistan and possible contaminant sources. Environmental Pollution 145: 839-849. doi:10.1016/j.envpol.2006.05.007

Government of Pakistan (2013) Fruit, vegetables and condiments statistics of Pakistan 2011-12. Ministry of National Food Security \& Research, Islamabad.

Government of Pakistan (2015a) Household Integrated Economic Survey 2013-14. Statistics Division, Pakistan Bureau of Statistics, Islamabad.

Government of Pakistan (2015b) Fruit, vegetables and condiments statistics of Pakistan 2013-14. Ministry of National Food Security \& Research, Islamabad.

Government of Pakistan (2015c) Crop Area and Production (By Districts) 2012-13 \& 2-13-2014. Ministry of National Food Security and Research (Economics Wing), Islamabad.

Government of Pakistan (2016a) Economic survey of Pakistan 2015-16. Ministry of Finance, Islamabad.

Government of Pakistan (2016b) Fruit, vegetables and condiments statistics of Pakistan 2014-15. Ministry of National Food Security \& Research, Islamabad.

Hassan S, Tabasam N, Iqbal J (2005) An economic analysis of wheat farming in the mixed farming zone of Punjab Province, Pakistan. Journal of Agriculture and Social Sciences 1: 167171.

Heady EO, Dillon J (1961) Agricultural Production Functions. Ames: Iowa State University Press.

Ibekwe UC, Adesope OM (2010) Analysis of dry season vegetable production in Owerri West local government area of Imo State, Nigeria. Journal of Development and Agricultural Economics 2: 245-249.

Khan REA, Ghafar S (2013) Technical efficiency of tomato production: A case study of district Peshawar (Pakistan). World Applied Sciences Journal 28: 1389-1392. DOI: 10.5829/idosi.aejaes.2013.13.11.11258

Mari FM (2009) Structure and efficiency analysis of vegetable production and marketing in Sindh, Pakistan. Ph.D. thesis submitted to the Sindh Agriculture University, Tando Jam, Pakistan.

Mohammed B (2015) Analysis of resource use efficiency and profitability in chilli pepper (Capsicum frutescens) production and its contribution to household farm income in Kaduna state. M.Sc. thesis submitted to the Ahmadu Bello University, Zaria.

Muhammad SA, Saghir A, Ashraf I, Asghar K, Kousar R (2015) An impact assessment of tunnel technology transfer project in Punjab, Pakistan. World Applied Sciences Journal 33: 33-37. DOI: 10.5829/idosi.wasj.2015.33.01.14565

Mwangi WJ (2012) Comparative analysis of greenhouse versus open-field small scale tomato production in Nakuru-North district, Kenya. M.Sc. thesis submitted to the Egerton University, Kenya.

Noonari S, Mmemon IN, Arain MU, Sidhu MY, Mirani AA, Khajjak AK, Sial SA, Jamali R, Jamali RH, Jamro AH (2015) Comparative economic analysis of hybrid tomato v/s conventional tomato production in district Tando Allahyar Sindh, Pakistan. Food Science and Quality Management 40: 114.

Olayiwola OO (2014) An economic analysis of chilli crop production in Ilora area of Oyo State. International Monthly Refereed Journal of Research, Management \& Technology 3: 47-53.

Ostertagová E, Ostertag O (2013) Methodology and Application of One-way ANOVA. American Journal of Mechanical Engineering 1: 256-261.

Patel VK (2014) An economic analysis of production and marketing of chilli (Capsicum annuum L.) in Raigarh district of Chhattisgarh. M.Sc. thesis submitted to the Department of Agricultural Economics, College of Agriculture, Raipur, India.

Poate CD, Daplyn PF (1993) Data for Agrarian Development. Cambridge University Press.

Sanusi MM, Ayinde IA (2013) Profitability of pepper production in derived Savannah zone of Ogun State, Nigeria. International Journal of Agriculture and Food Security 4: 401410 .

Teddlie C, Yu F (2007) Mixed methods sampling: A typology with examples. Journal of Mixed Methods Research 1: 77-100. DOI: $10.1177 / 2345678906292430$.

Velayutham LK, Damodaran K (2015) An economic analysis of chillies production in Guntur district of Andhra Pradesh. International Journal of Research in Economics Social Sciences 5: 43-49. 